\title{
Pyridone-based nucleotide analogues accepted for DNA biosynthesis
}

\author{
Algirdas Mikalkènas ${ }^{1}$, \\ Bazilè Ravoitytè $\dot{e}^{1,2}$, \\ Daiva Tauraité ${ }^{3,4}$, \\ Saulius Serva ${ }^{1,4 \star}$ \\ ${ }^{1}$ Department of Biochemistry \\ and Molecular Biology, \\ Institute of Biosciences, \\ Vilnius University, Sauletekio al. 7, \\ Vilnius LT-10257, Lithuania \\ ${ }^{2}$ Laboratory of Genetics, \\ Nature Research Centre, Akademijos 2, \\ Vilnius LT-08412, Lithuania \\ ${ }^{3}$ Department of Molecular Microbiology \\ and Biotechnology, Institute of Biochemistry, \\ Vilnius University, Sauletekio al. 7, \\ Vilnius LT-10257, Lithuania \\ ${ }^{4}$ Department of Chemistry \\ and Bioengineering, \\ Vilnius Gediminas Technical University, \\ Sauletekio al. 11, Vilnius LT-10223, Lithuania
}

Novel pyridone-based nucleotides were investigated for maintenance of DNA synthesis, carried on by representatives of different classes of polymerases. Five different nucleoside triphosphates of similar structure were addressed, demonstrating involvement in primer extension. The nucleotides containing 4-chloro- and 4-bromo-2-pyridone as a nucleobase were preferred by all DNA polymerases tested. These nucleotides were incorporated up to several instances in a row and unexpectedly failed to ensure DNA primer termination. Temporary polymerase stalling obeys kinetic constrain and is alleviated by availability of nucleotides readily acquired by the polymerase. Lack of inhibitory properties of 2-pyridone nucleobase confirms the processivity of DNA polymerases challenged by incorporated nucleotides.

Keywords: 2-Pyridone, modified nucleotide, DNA polymerase, inhibition

\section{INTRODUCTION}

Deoxyribonucleotides comprise building blocks of DNA and have numerous important applications, including DNA amplification and labeling (Niida et al., 2010; Gandhi, Samuels, 2011). Modified nucleotides can also be incorporated into nucleic acid either alone or in competition with their natural counterparts. They act as antitumor and antiviral agents via inhibition of various enzymes, DNA

\footnotetext{
* Corresponding author. E-mail: saulius.serva@gf.vu.lt
}

and RNA polymerases including (Deval et al., 2014; Sinha et al., 2004). Nucleoside analogues have been in clinical use for almost 50 years and have become cornerstones of treatment for patients with cancer or viral infections (Jordheim et al., 2013). Currently, eight nucleoside RT inhibitors are approved as AIDS drugs (Das et al., 2016), constituting the essence of revolutionary HAAR treatment. Periodically, new drugs are required to be added to the pool of available drugs for broader or better treatment options for patients facing adverse side effects or resistance challenges to current drugs. 
Modified base pairs accepted by polymerases are essential for creation of new forms of xeno-DNA (Kool 2008). Initial efforts to expand the genetic code introduced the isoC-isoG pair (Piccirilli et al., 1990). Non-polar isosteres of natural DNA bases (Schweitzer, Kool, 1994) were designed proposing the structures lacking hydrogen bonding groups, constituting the closest possible structural mimics of natural bases. DNA polymerases nevertheless demonstrated high fidelity even when a base pair completely lacked the polar Watson-Crick hydrogen bonds. Nucleoside derived from difluorotoluene, a nonpolar nucleoside analogue identical to thymidine in size, shape, and conformation, upon positioning within a DNA strand opposite adenine paired with high fidelity and efficiency (Moran et al., 1997; Moras et al., 1997). These examples provided base requirements for the design of modified nucleobases in order to be accepted by biologic systems.

In this work, we investigated five novel nucleoside triphosphates bearing 2-pyridone as a nucleobase. All of them were competent for incorporation into DNA by Klenow exo- polymerase; however, the efficiency of acquisition varied significantly. 4-Chloro- and 4-bromo2-pyridone nucleotides were progressively incorporated into DNA by the polymerases employed. Both moieties failed to ensure primer termination, leading to efficient DNA extension by the natural counterpart.

\section{MATERIALS AND METHODS}

For the acceptance of nucleotides for DNA biosynthesis, reactions were performed as described (Tauraite et al., 2015) with further modifications. In short, duplex DNA comprising 5' ${ }^{33} \mathrm{P}$ labeled primer oligodeoxyribonucleotide 5'-TAATACGACTCACTATAGGGAGA and template "A" oligodeoxyribonucleotide 5'-CCGGAATTAAAATCTCCCTATAGTGAGTCGTATTA, was annealed by heating for $5 \mathrm{~min}$ at $95^{\circ} \mathrm{C}$ and gradually cooling down to the room temperature over $2 \mathrm{~h}$. DNA duplex (5 $\mathrm{nM})$ was subjected to primer extension reactions in the presence of $50 \mathrm{nM}$ polymerases Klenow exo-, M.MuLV, or HIV-1 in a reaction mix comprising $20 \mathrm{mM}$ sodium glutamate, $\mathrm{pH}$ 8.2, $10 \mathrm{mM}$ DTT, $0.5 \%$ Triton X-100, $20 \mathrm{mM}$ sodium chloride and $1 \mathrm{mM}$ magnesium chloride. The reactions were performed for 5,15 or $60 \mathrm{~min}$ as described at $37^{\circ} \mathrm{C}$ in the presence of $0.1-1000 \mu \mathrm{M}$ compounds $\mathbf{1 - 5}$. The reactions were terminated by adding an equal volume of STOP solution, containing 95\% deionized formamide and $25 \mathrm{mM}$ EDTA. The products were resolved on a $15 \%$ 19:1 denaturing ( $8 \mathrm{M}$ urea) polyacrylamide gel, the gel was dried on Whatman paper and autoradiographed using a phosphorimager screen.

For the analysis of incorporation specificity, four different template oligodeoxyribonucleotides were employed for DNA duplex formation (residues governing nature of first and subsequent nucleotides to be incorporated are bolded):

5'-CCGGAATTAAAATCTCCCTATAGTGAGTCGTATTA (Template "A");

5’-TTAAGGCCGGGGTCTCCCTATAGTGAGTCGTATTA (Template “G”);

5'-CCGGTTAATTTTTCTCCCTATAGTGAGTCGTATTA (Template “T”);

5'-TTAACCGGCCCCTCTCCCTATAGTGAGTCGTATTA (Template “C”).

\section{RESULTS AND DISCUSSION}

Synthesis of novel 2-pyridone-based nucleosides and nucleotides has recently been reported (Tauraitè et al., 2016). Evaluation of polymerase-driven DNA synthesis uncovered rather minute - if any - property of 2-pyridone-based nucleosides to inhibit DNA extension. Incompatibility of active sites of polymerases involved in a testing with the structure of nucleobase analogues offered a most plausible explanation for this effect. However, several nucleoside triphosphates involving 2-pyridone nucleobase analogues were found to be competent for incorporation into the DNA.

Here we evaluate in detail the efficiency of acquisition of five 2-pyridone-based nucleotides (Fig. 1, 1 to 5 ) by different DNA polymerases in a highly controllable assay of single nucleotide resolution. In this assay, radioactively 
<smiles>O=c1ccccn1[C@H]1C[C@@H](O)[C@@H](COP(=O)(O)OP(=O)(O)OP(=O)(O)O)O1</smiles>

3-hydroxy-5-(2-oxo-1-pyridyl) tetrahydrofuran-2-yl)methyl triphosphate<smiles>O=c1cc(O)ccn1[C@H]1C[C@H](O)[C@@H](COP(=O)(O)OP(=O)(O)OP(=O)(O)O)O1</smiles>

3-hydroxy-5-(4-hydroxy-2-oxo-1pyridyl) tetrahydrofuran-2-yl)methyl triphosphate<smiles>O=c1cc(Cl)ccn1[C@H]1C[C@H](O)[C@@H](COP(=O)(O)OP(=O)(O)OP(=O)(O)O)O1</smiles>

5-(4-chloro-2-oxo-1-pyridyl)-3hydroxytetrahydrofuran-2-yl)methyl triphosphate<smiles>O=c1cc(Br)ccn1[C@H]1C[C@@H](O)[C@@H](COP(=O)(O)OP(=O)(O)OP(=O)(O)O)O1</smiles>

5-(4-bromo-2-oxo-1-pyridyl)-3hydroxytetrahydrofuran-2-yl)methyl triphosphate<smiles>O=C(O)c1ccc(=O)n([C@H]2C[C@H](O)[C@@H](COP(=O)(O)OP(=O)(O)OP(=O)(O)O)O2)c1</smiles>

5-(5-carboxy-2-oxo-1-pyridyl)-3hydroxytetrahydrofuran-2-yl)methyl triphosphate

Fig. 1. Modified nucleotides involved in the study labeled DNA primer is hybridized to the template strand to form fully complementary duplex bearing 3' single-stranded region, directing primer extension by single deoxynucleoside triphosphate up to four consecutive events in a row (Fig. 2A). Since the 2-pyridone nucleobase structure is genuinely different from the natural pyrimidine moieties, Watson-Crick hybridization is uncertain thus raising the need for a universality of template. We addressed this constrain by designing four separate assay systems, one for each of a natural nucleobase in the directing region of a template. In addition, a broad range of timescales and 2-pyridone nucleotide concentrations were employed.

To confirm the previous observation of DNA extension, we first addressed all five compounds for incorporation into DNA primer by M.MuLV reverse transcriptase (Fig. 2B, top picture) employing the most efficient template $\mathrm{A}$, as determined earlier. Quite surprisingly, four out of five compounds (1, 3, 4 and 5) exhibited the property to be employed by enzyme, albeit at markedly different efficiencies. As observed previously, compounds 3 and $\mathbf{4}$ are acquired most efficiently; interestingly, 3 was found to determine the second incorporation event (see the corresponding lane in Fig. 2B, top picture). We went on by addressing Klenow exo- DNA polymerase in the same setup (Fig. 2B, bottom picture) and observed even more efficient primer extension - up to three or four (for compound 3) incorporation events. Thus, we conclude the general acceptance of all compounds tested by polymerase; again, efficiencies of primer extension vary greatly, retaining the same distribution between the nucleotides toward the acceptance by polymerases involved in a testing. Of note are experiment conditions, enabling to uncover this phenomenon - we used $100 \mu \mathrm{M}$ compounds, and the reaction was set to proceed for a 15 min instead of $1-10 \mu \mathrm{M}$ and 5 min reaction time, as was used in Tauraite et al., 2016.

The observation of primer extension significantly beyond the single residue prompted us to re-evaluate the kinetic parameters of the assay. We therefore performed an extended testing of time- and concentration-related restrains 


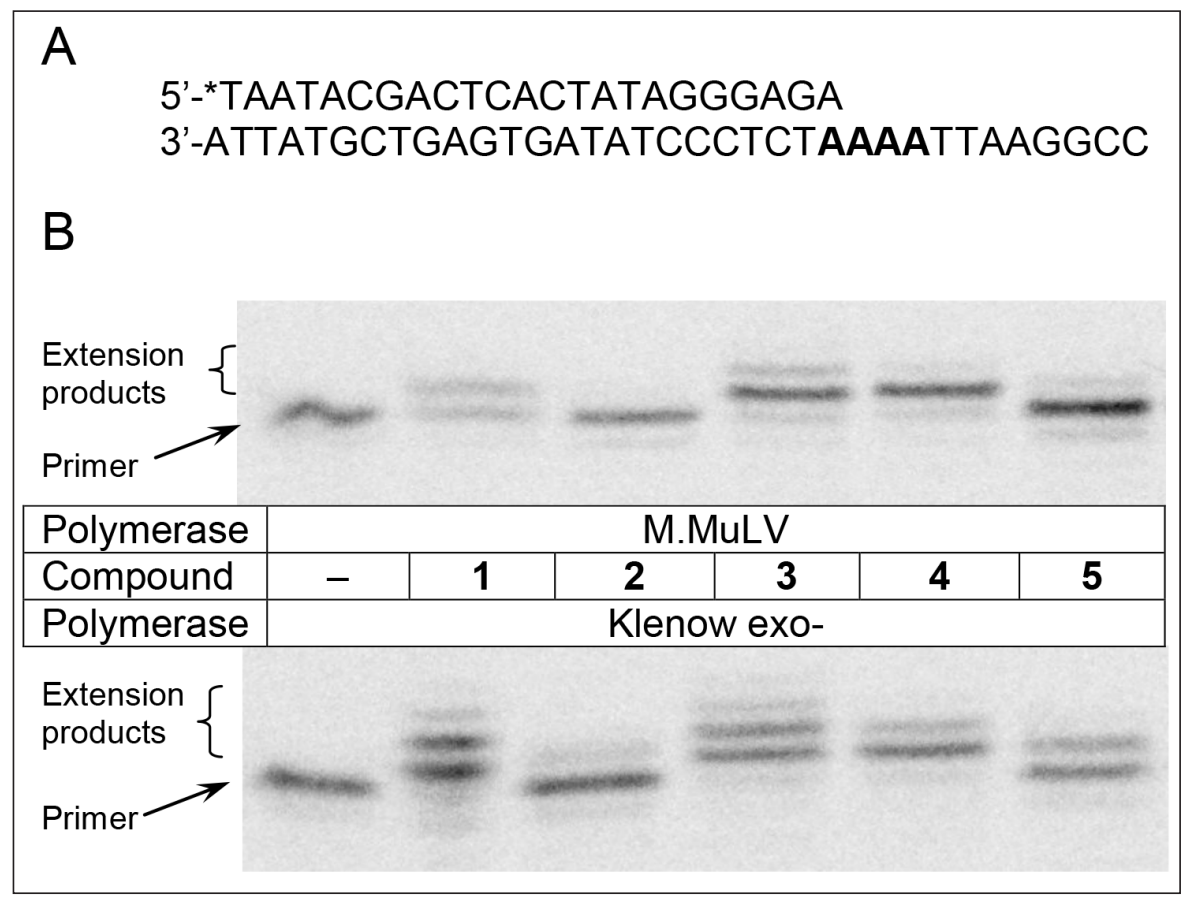

Fig. 2. (A) DNA template/primer duplex used for the study. Asterisk indicates 5' terminal ${ }^{33}$ P-labeled nucleotide. (B) Autoradiograms of primer extension reactions, performed in the presence of $100 \mu \mathrm{M}$ compounds 1 to 5 (middle row of table) by polymerases disclosed in the rows next to the picture

involving most efficiently performing compounds 3 and 4 . Figure 3A illustrates the performance of the selected setup described in the legend table. The kinetic character of the primer extension by Klenow exo- polymerase was immediately clear because of gradual increasing of product size over time ( 5 or $60 \mathrm{~min}$ ) and concentration of nucleotide ( 0.1 to $1000 \mu \mathrm{M})$ used. The same character of the reaction was uncovered by the use of M.MuLV reverse transcriptase in case of compounds 3 (Fig. 3B, top picture) and 4 (Fig. 3B, bottom picture) and HIV-1 reverse transcriptase involving 3 and 4 (not shown). As was observed earlier in this study, both reverse transcriptases possess lower efficiency toward all 2-pyridone nucleotides employed comparing to Klenow exo- (compare Fig. 3A and 3B), albeit the kinetic character of primer extension is retained. We also addressed template requirements for incorporation of compounds $\mathbf{3}$ and $\mathbf{4}$ by all three enzymes and found the rest templating nucleotides ( $C, G$ and $T$ ) be effective for a sin- gle - if any - primer extension event only, (not shown). Among these, G remains the most permissive and further confirms our previous findings (Tauraitè et al., 2016).

The multiple primer extension events observed by virtue of compounds 3 and $\mathbf{4}$ prompted us to evaluate such extended DNA for a chain termination property. We performed DNA primer extension by Klenow exo- and $10 \mu \mathrm{M}$ compounds $\mathbf{3}$ and $\mathbf{4}$ under conditions designed to obtain uniform primer extension by single nucleotide only (Fig. 4A, lanes 2 and 3). Upon completion of the reaction, aliquots of these samples were supplemented with an equal molar amount of dTTP and reaction set to proceed. As evidenced in lanes 5 and 6 of Fig. 4A, primer extension proceeded completely up to the allowed limit of 4 consecutive residues. The observed complete primer extension, independent of the initial extension step, proves the ability of involved DNA polymerase - Klenow exo- in this case - to employ 4-chloro- and 4-bromo-2-pyridone nucleobase-terminated DNA for further 


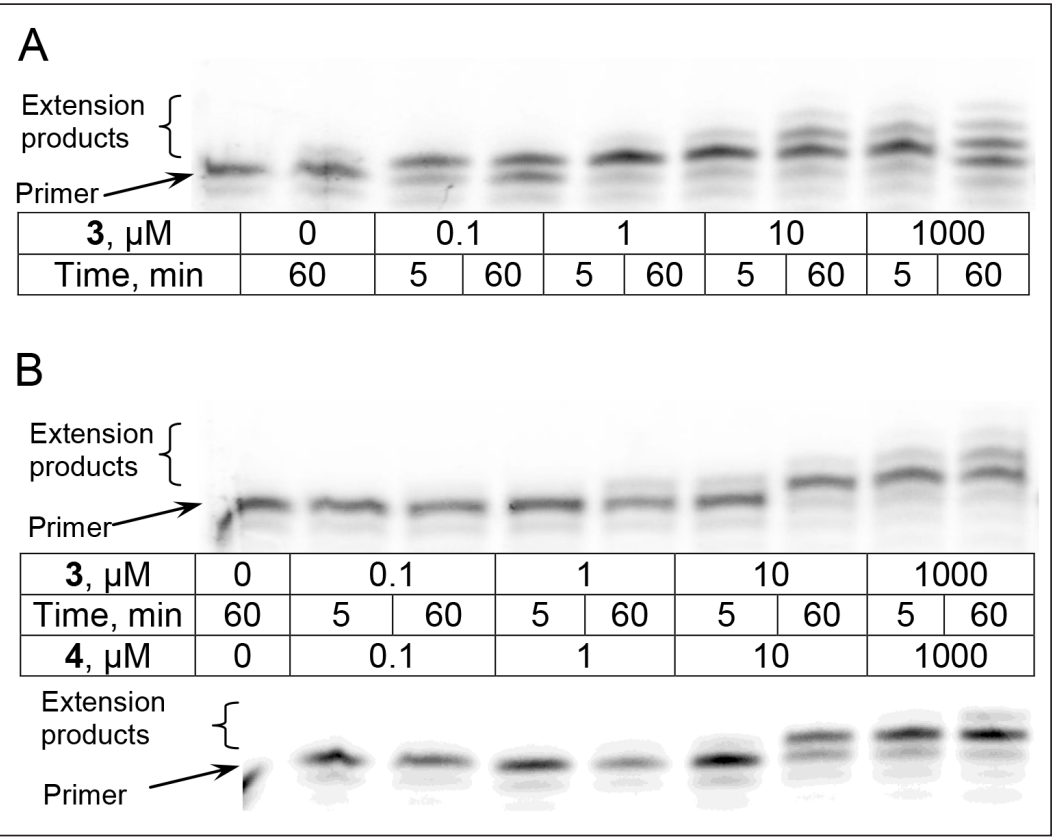

Fig. 3. Autoradiograms of primer extension reactions by the use of (A) Klenow exo- in the presence of various concentrations (table top row) of compound 3; (B) M.MuLV in the presence of various concentrations (table top and bottom rows) of compounds 3 (top picture) and 4 (bottom picture). Reaction duration disclosed in (A) bottom row or (B) middle row of the legend tables

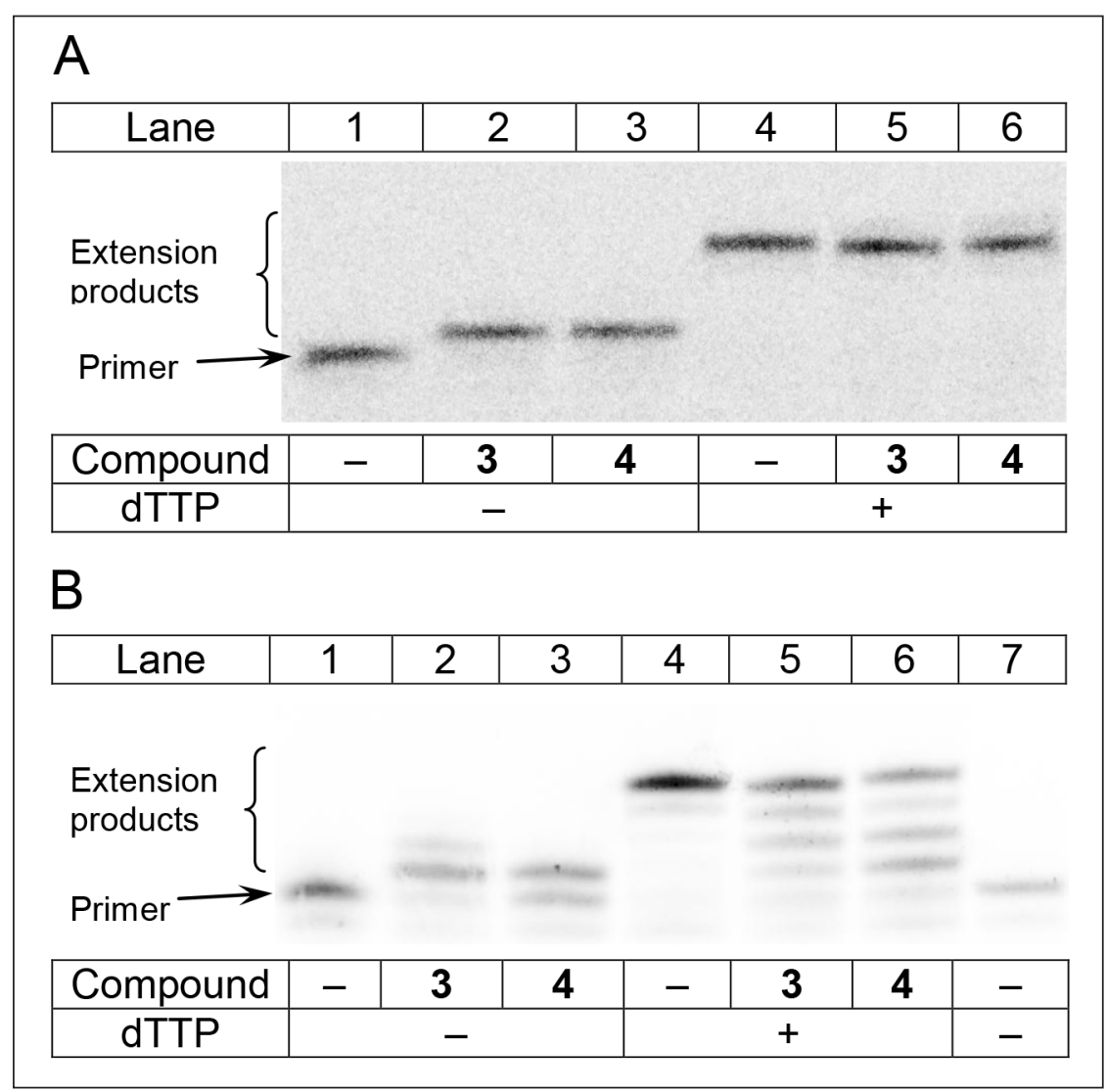

Fig. 4. Autoradiograms of primer extension reactions by the use of (A) Klenow exo- in the presence of $10 \mu \mathrm{M}$ compounds 3 or 4 ; (B) M.MuLV in the presence of $1000 \mu \mathrm{M}$ of compounds 3 or 4 . Under completion of the first reaction set to proceed for $5 \mathrm{~min}$, dTTP was added up to $10 \mu \mathrm{M}$ and primer extension was prolonged for another $5 \mathrm{~min}$, as indicated by bottom row of the legend table 
extension. We also employed a similar setup involving M.MuLV reverse transcriptase (Fig. 4B). In line with previous observation, DNA primer extended by use of $1000 \mu \mathrm{M}$ compounds 3 and 4 (lanes 2 and 3) was further elongated up to the allowed limit (lanes 5 and 6) following the addition of $10 \mu \mathrm{M}$ dTTP. Here, intermediates of primer extension are still present, resulting from the unfavourable ratio of dTTP (provided in 100x fewer amount over 3 and 4). This observation further uncovers the competition range between natural and 2-pyridone based nucleoside triphosphates for M.MuLV-maintained primer extension.

Nucleobase is generally accepted as the most permissive part of nucleotides for modification to prepare catalytically competent nucleotide analogues. Pyrimidine C5 position is considered as standard for conjugation of moieties of interest and retains Watson-Crick hybridization property involving natural partner at the complementing position. Numerous self-complementary duplexes were elaborated, involving both artificial partners held together by hydrophobic forces (Stambasky et al., 2009); some of them are competent for recognition by DNA polymerase as well. While a number of benzene, naphthalene, pyridine, indole, and other $\mathrm{C}$ - and $\mathrm{N}$-nucleoside analogues were employed to comprise base pairs, un-disturbing the structure of B form DNA, addition of an analogue partner to a natural counterpart rarely leads to such a result. 2-Pyridone nucleobases, described in this study (Fig. 1), not only lack N3 of pyrimidine; $\mathrm{C} 4$ position (C5 in case of compound 5) is highlighted by moieties not occurring in natural nucleobases. A significant impact on the structure of DNA involving such nucleobases is genuinely expected, leading to a failure of further extension by DNA polymerases. We first observed DNA extension by one or several 2-pyridone-based nucleotides in a row, indicating unusual robustness of polymerases toward novel nucleobase analogues. Furthermore, a rather effective involvement of primer with one or several 3'-terminal 4-chloroand 4-bromo-2-pyridone nucleotides in the polymerization reaction carried on by natural nucleotides was discovered. While 4-chloro- and 4-bromo-2-pyridone based nucleotides were used for polymerization reaction at a significantly higher concentration- and time-frames comparing to natural nucleotides, the incorporation obstacles appear to be of a clearly kinetic origin. This is further confirmed by lack of inhibitory properties of 2-pyridone nucleosides on engaged DNA polymerase and reverse transcriptases, as observed earlier (Tauraite et al., 2016). Structural flexibility of DNA polymerases involved in the study is expected to play a crucial role in acquisition of 2-pyridone-based nucleotides. The observed most effective primer extension by Klenow exo- is quite surprising, given the general recognition of reverse transcriptases as most versatile enzymes for incorporation of modified nucleobases into DNA. On the other hand, processivity for Klenow exo- is well known to significantly exceed that of M.MuLV and HIV-1 reverse transcriptases, providing them with an acceptable rationale for observations. Further research is needed to elucidate this phenomenon and versatility of alike nucleotides for DNA labeling.

In summary, we investigated five novel nucleoside triphosphates bearing 2-pyridone as a nucleobase. All of them were competent for incorporation into DNA by Klenow exo- polymerase, albeit at markedly different efficiencies. 4-chloro- and 4-bromo-2-pyridone nucleotides were progressively incorporated into DNA by several polymerases under the control of a kinetic constrain. Both moieties failed to ensure primer termination, leading to efficient DNA extension by a natural counterpart.

\section{ACKNOWLEDGEMENTS}

This work was supported by the Research Council of Lithuania, project No. MIP-035/2014.

Received 24 December 2016 Accepted 16 March 2017

\section{References}

1. Das K, Balzarini J, Miller MT, Maguire AR, DeStefano JJ, Arnold E. Conformational 
states of HIV-1 reverse transcriptase for nucleotide incorporation vs pyrophosphorolysis - binding of foscarnet. ACS Chem. Biol. 2016; 11: 2158-64.

2. Deval J, Symons JA, Beigelman L. Inhibition of viral RNA polymerases by nucleoside and nucleotide analogs: Therapeutic applications against positive-strand RNA viruses beyond hepatitis C virus. Curr. Opin. Virol. 2014; 9: $1-7$.

3. Gandhi VV, Samuels DC. A review comparing deoxyribonucleoside triphosphate (dNTP) concentrations in the mitochondrial and cytoplasmic compartments of normal and transformed cells. Nucleos. Nucleot. Nucl. 2011; 30: 317-39.

4. Jordheim LP, Durantel D, Zoulim F, Dumontet C. Advances in the development of nucleoside and nucleotide analogues for cancer and viral diseases. Nat. Rev. Drug Disc. 2013; 12: 447-64.

5. Kool ET. Modified DNA bases: probing basepair recognition by polymerases, in modified nucleosides, in Herdewijn P, editor. Biochemistry, Biotechnology and Medicine. Weinheim, Germany: WILEY-VCH Verlag GmbH KGaA; 2008. p. 49-74.

6. Moran S, Ren RXF, Rumney IV S, Kool ET. Difluorotoluene, a nonpolar isostere for thymine, codes specifically and efficiently for adenine in DNA replication. J. Am. Chem. Soc. 1997; 119: 2056-57.

7. Moras S, Ren RXF, Kool ET. A thymidine triphosphate shape analog lacking WatsonCrick pairing ability is replicated with high sequence selectivity. Proc. Natl. Acad. Sci. USA. 1997; 94: 10506-11.

8. Niida H, Shimada M, Murakami H, Nakanishi M. Mechanisms of dNTP supply that play an essential role in maintaining genome integrity in eukaryotic cells. Cancer Sci. 2010; 101: 2505-9.

9. Piccirilli JA, Krauch T, Moroney SE, Benner SA. Enzymatic incorporation of a new base pair into DNA and RNA extends the genetic alphabet. Nature. 1990; 343: 33-7.
10. Schweitzer BA, Kool ET. Aromatic nonpolar nucleosides as hydrophobic isosteres of pyrimidines and purine nucleosides. J. Org. Chem. 1994; 59: 7238-42.

11. Sinha S, Srivastava R, Clercq ED, Singh RK. Synthesis and antiviral properties of arabino and ribonucleosides of 1,3-dideazaadenine, 4-nitro-1,3-dideazaadenine and diketopiperazine. Nucleos. Nucleot. Nucl. 2004; 23: 1815-24.

12. Stambasky J, Hocek M, Kocovsky P. C-Nucleosides: synthetic strategies and biological applications. Chem. Rev. 2009; 109: 6729-64.

13. Tauraitė D, Dabužinskaitė J, Ražanas R, Urbonavičius J, Stankevičiūtė J, Serva S, Meškys R. Synthesis of novel derivatives of 5-carboxyuracil. Chemija 2015; 26: 120-5.

14. Tauraitė D, Ražanas R, Mikalkènas A, Serva S, Meškys R. Synthesis of pyridone-based nucleoside analogues as substrates or inhibitors of DNA polymerases. Nucleos. Nucleot. Nucl. 2016; 35(4): 163-77.

\section{Algirdas Mikalkẻnas, Bazilė Ravoitytė, Daiva Tauraité, Saulius Serva \\ DNR BIOSINTEZEI TINKAMI PIRIDONINIAI NUKLEOTIDŲ ANALOGAI}

\section{Santrauka}

Naujų piridoninių nukleotidų gebejjimas dalyvauti DNR sintezèje įvertintas tiriant kelių skirtingų polimerazių šeimų atstovus. Aptikta, kad visi penki dTTP analogai gali būti panaudoti pradmens pratęsimo reakcijose. 4-chlor- ir 4-brom-2-piridono nukleotidai geriausiai tiko iš visų tirtų DNR polimerazių. Šie nukleotidai ịtraukiami laipsniškai, o vis mažejjantis kito nukleotido įtraukimo efektyvumas nesusijęs su DNR grandinès terminacija. DNR polimerazių neaktyvumas paklūsta kinetiniams reakcijos apribojimams ir gali būti neutralizuotas pridejjus natūralų nukleotidą. Piridono nukleobazių sąlygoto slopinimo nebuvimas patvirtina DNR polimerazių veiklos blokavimo mechanizmą.

Raktažodžiai: 2-piridonas, modifikuoti nukleotidai, DNR polimerazès, slopinimas 